\title{
Effect of Cucumber Extract on Soybean Lipoxygenase Activity and the Functional Properties of Soybean Protein Concentrate
}

\author{
Yuepeng Wang \\ Graduate School of Life and Environmental Sciences \\ University of Tsukuba \\ 1-1-1 Tennodai, Tsukuba 305-8577, Ibaraki, Japan
}

Tel: 81-29-853-6972Ｅ-mail: ouetsuhou@hotmail.com

Yingnan Yang

Graduate School of Life and Environmental Sciences

University of Tsukuba

1-1-1 Tennodai, Tsukuba 305-8577, Ibaraki, Japan

Tel: 81-29-853-8830 E-mail: yo.innan.fu@u.tsukuba.ac.jp

\section{Min Shi}

Graduate School of Life and Environmental Sciences

University of Tsukuba

1-1-1 Tennodai, Tsukuba 305-8577, Ibaraki, Japan

Tel: 81-29-853-6972Ｅ-mail: shimin0816@gmail.com

\section{Yiting Li}

Graduate School of Life and Environmental Sciences

University of Tsukuba

1-1-1 Tennodai, Tsukuba 305-8577, Ibaraki, Japan

Tel: 81-29-853-6972Ｅ-mail: liyitingyoyo@hotmail.com

\section{Ying Zhang}

Graduate School of Life and Environmental Sciences

University of Tsukuba

1-1-1 Tennodai, Tsukuba 305-8577, Ibaraki, Japan

Tel: 81-29-853-6972Ｅ-mail: syyd63gm13@yahoo.co.jp

Zhenya Zhang (Corresponding author)

Graduate School of Life and Environmental Sciences

University of Tsukuba

1-1-1 Tennodai, Tsukuba 305-8577, Ibaraki, Japan

Tel: 81-29-853-4712Ｅ-mail: tyou6688@sakura.cc.tsukuba.ac.jp

Received: November 11, 2011

doi:10.5539/ijb.v4n1p111
Accepted: November 29, 2011

Published: January 1, 2012

URL: http://dx.doi.org/10.5539/ijb.v4n1p111 


\begin{abstract}
The inhibition effect on the soybean lipoxygenase of cucumber extracted by hexane, ethyl acetate, butyl alcohol and methyl alcohol was investigated, in order to determine the inhibitory activity of soybean protein concentrate.The hexane-soluble fraction exhibited superior inhibitory activity with inhibition percentage of $80.24 \%$ at concentration of $2 \mathrm{mg} / \mathrm{ml}$. The soybean protein concentrate (HSPC) was prepared by washing the low-temperature defatted soybean flour (DSF) with the mixture of $65 \%$ ethanol $(\mathrm{v} / \mathrm{v})$ and various amount of hexane-soluble fraction. Then the residual activity of HSPC was measuredand the minimum residual activityofHSPC $(3.77 \pm 0.69 \mathrm{U})$ was observed at the ratio of $0.3 \mathrm{mg}$ cucumber hexane-soluble fraction to $5 \mathrm{~g}$ DSF. It was closed to that of commercial soybean protein concentrate(SPC). Solubility, emulsifying, foaming and oil absorption properties of HSPC were investigated. It was observed that when $\mathrm{pH}$ was less than 3 and more than 5, HSPC showed superior solubility compared with commercial SPC. Emulsifying properties of HSPC exhibited significant higher values of emulsion stability index and emulsifying activity index than those of commercial SPC. Foaming characteristics of HSPC exhibited similar foaming capacity and excellent foaming stability compared with commercial SPC. Oil absorption capacity of HSPC was higher than commercial SPC significantly.
\end{abstract}

Keywords: Lipoxygenase, Soybean protein concentrate, Functional properties

\title{
1. Introduction
}

Soy protein presents extraordinary nutritional and functional properties as compared to other animal and vegetal proteins. In particular, it has been demonstrated that this protein has certain medical applications(Emmert and Baker 1995),therefore the use of soy protein as functional ingredients in food products is gaining interest and demand (Tiziani and Vodovotz 2005). However, the soybean and green flavors of soybean formed during processing and cooking have hindered its wide utilization (Yukawa et al. 1992). The major contributors to these flavors are the volatile carbonyl compounds which are enzymatically derived from the hydroperoxides of unsaturated fatty acids by soybean lipoxygenase(Rackis et al. 1979). Lipoxygenase (linoleate: oxygen reductase; EC 1.13.11.12) is an enzyme that catalyzes the oxidation of linoleic acid and other polyunsaturated fatty acids containing a cis,cis-1,4-pentadiene moiety to hydroperoxy fatty acids by hydrogen abstraction from the methylene carbon and antarafacial insertion of molecular oxygen (Ivanov et al. 2010). These fatty acid hydroperoxides (HPODs) considered to be flavor precursors (Anderson 1992; Andreou and Feussner 2009), are subsequently converted by enzymatic cleavage into flavor compounds, including ketones, aldehydes and alcohols (Kermasha et al. 2002).

Heat treatment is the most widely utilized method for inactivating lipoxygenase. However, heat treatment produces a negative impact on foundation properties and induces dissociation, denaturation and aggregation of soy protein (Anderson 1992; Sorgentini et al. 1995).

Nonadienal and other volatile C9 compounds are characteristic compounds of cucumber fruits and seedlings. Their biosynthesis is proposed to take place by cleavage of 9-hydroperoxi-octadecadienoic acid which results from the action of lipoxygenase on linoleate(Feußner and Kindl 1992). But when we eat cucumber,could not feelthe similar smellikethe odour ofsoybean. Therefore,cucumbermaybe contain inhibitory compound on lipoxygenase activity.

The objective of this work was to investigate possibility of the cucumber extract being a substitute for thermal treatment to inhibit lipoxygenase activity. Currently, the functional properties of HSPC were determined.

\section{Materials and Methods}

\subsection{Materials}

Soybean was purchased from market. SPC was provided from manufacturer of China. Hexane, ethyl acetate, butyl alcohol, methyl alcohol, ethyl alcohol, linoleic acid and tween 20 were purchased from Wako Pure Chemical, Osaka. Hexane, ethyl acetate, butyl alcohol, methyl alcohol, ethyl alcoholwere of guaranteed reagent. All others reagents and chemicals were of analytical reagent.

\subsection{Preparation of cucumber extracts}

Dried cucumber flour was macerated with $\mathrm{MeOH}(1: 10, \mathrm{w} / \mathrm{v})$ at room temperature for $12 \mathrm{~h}$ with constant stirring. The process was repeated twice with fresh extractant.The resulting extracts were combined, filtered, concentrated in vacuo to get the crude extract. This extract was suspended in deionized water and successively partitioned with hexane, EtOAc, and $\mathrm{BuOH}$ to afford a hexane-soluble fraction, an EtOAc-soluble fraction and a $\mathrm{BuOH}$-soluble fraction. The remainingaqueous phase wasregarded as $\mathrm{MeOH}$-soluble fraction.The 
resultingextracts were combined, filtered, concentrated and lyophilizedand stored at low temperature $\left(4 \pm 2^{\circ} \mathrm{C}\right)$ in dark for further use.

\subsection{Preparation of low-temperature defatted soybean flour (DSF)}

Preparation of low-temperature defatted soybean flour was performed according to a previously described procedure with some modifications(Kong et al. 2008). Soybean was cleaned and dried in an electric oven at $40{ }^{\circ} \mathrm{C}$ for $12 \mathrm{~h}$ to the moisture content below $8 \%$. The dried soybean was dehulled, ground to 60 mesh and defatted with hexane at room temperature and allowed to dry in a fume hood to prepare low-temperature defatted soybean flour.

\subsection{Soybean lipoxygenase inhibition assay}

In order to determine which fraction could effectively inhibit the lipoxygenase activity, the following experiments were performed.

\subsubsection{Preparation of linoleic acid substrate}

Linoleic acid substrate was prepared according to Yen et al(Yen et al. 2003) with some modifications. Linoleic acid of $0.2 \mathrm{~g}$ and tween 20 of $0.2 \mathrm{~g}$ as emulsifier and $10 \mathrm{ml}$ sodium borate buffer $(0.2 \mathrm{M}, \mathrm{pH} 9.0)$ were mixed. The mixture was homogenized by magnetic stirrer, added sufficient $1 \mathrm{MNaOH}$ to yield a clear solution, adjusting $\mathrm{pH}$ to 9.0 by $1 \mathrm{M} \mathrm{HCl}$ and added sodium borate buffer $(0.2 \mathrm{M}, \mathrm{pH} 9.0)$ to $100 \mathrm{ml}$.

\subsubsection{Preparation of thecrude soybean lipoxygenase}

The crude soybean lipoxygenase was preparedaccording to the modified method of Hanqing(Hanqing 1996). DSF was blended with 200 volumes (w/v) of sodium phosphate buffer $(0.01 \mathrm{M}, \mathrm{pH} 7.0)$ in a beaker and homogenized by magnetic stirrer for $1 \mathrm{~h}$ at room temperature. The mixture was centrifuged at $10000 \mathrm{~g}$ for $30 \mathrm{~min}$. The supernatant was crude enzyme extract and diluted to one-third with sodium phosphate buffer $(0.01 \mathrm{M}, \mathrm{pH} 7.0)$ before use.

\subsubsection{Preparation of samples of cucumber extracts}

Sufficient extracts were dissolved by using $0.2 \%$ tween 20 sodium phosphate buffer $(0.01 \mathrm{M}, \mathrm{pH} 7.0)$ solution to $2 \mathrm{mg} / \mathrm{ml}$, respectively. The extract solutions were then diluted to $0.67,0.8,1,1.33,2 \mathrm{mg} / \mathrm{ml}$ using $0.2 \%$ tween 20 sodium phosphate buffer solution, respectively.

\subsection{In vitro lipoxygenase inhibition assay}

Lipoxygenase activity was measured using a continuous spectrophotometric rate method based on the enzymatic oxidation of linoleic acid to the hydroperoxide of linoleic acid, following a modified procedure described by Indrawsti et al (Indrawati et al. 2000), with some modifications. $0.5 \mathrm{ml}$ of fresh crude soybean lipoxygenase was incubated with $0.5 \mathrm{ml}$ extract solutionsof different concentrations $(0.67,0.8,1,1.33,2 \mathrm{mg} / \mathrm{ml})$ for $30 \mathrm{~min}$ at $25^{\circ} \mathrm{C}$, respectively. Then $2.5 \mathrm{ml}$ boric acid buffer $(0.2 \mathrm{M}, \mathrm{pH} 9.0)$ and $0.3 \mathrm{ml}$ linoleic acid solution were added into a $10 \mathrm{~mm}$ path length quartz cuvette. The reaction was initiated by the addition of $0.2 \mathrm{ml}$ incubatedcrudesoybean lipoxygenaseand the conversion of linoleic acid to 13-hydroperoxylinoleic acid was measured immediately at $234 \mathrm{~nm}$ for $5 \mathrm{~min}$ at $25^{\circ} \mathrm{C}$ by a spectrophotometer (UV-3100PC, shimadzu). Thecontrol was prepared with $2.6 \mathrm{ml}$ boric acid buffer, $0.3 \mathrm{ml}$ linoleic acid solution and $0.1 \mathrm{ml}$ crude soybean lipoxygenase without incubating. The controlwas recalibratedbefore the extract was changed. The activity was determined by the slope of the linear portion of theabsorbencycurve.The inhibition ratio and $\mathrm{IC}_{50}$ of extracts were calculated. The $\mathrm{IC}_{50}$ is the concentration of extract which inhibited $50 \%$ activity of soybean lipoxygenase. The inhibition ratio of lipoxygenase activity by extracts was calculated as:

$$
\text { inhibition }(\%)=\left[\frac{\mathrm{S}_{\mathrm{C}}-\mathrm{S}_{\mathrm{S}}}{\mathrm{S}_{\mathrm{S}}}\right]
$$

whereSc and Ss were the slope of the reaction curve of thecontrol and the sample, respectively. All resultswere an average of at least triplicate measurements.

\subsection{Preparation of HSPC}

2.6.1 Residual activity of soybean lipoxygenase of HSPC treated by various amount of hexane -soluble fraction

In order to obtain the minimum residual activity of soybean lipoxygenase, the relation betweenhexane -soluble fraction amount and residual activity of soybeanlipoxygenase of HSPC was determined. 
HSPC was prepared as follows: Low-temperature defatted soybean flour $(5 \mathrm{~g})$ was soaked in the mixture containing $65 \%$ aqueous alcohol $(1: 10, \mathrm{w} / \mathrm{v})$ and hexane-soluble fraction $(0.2,0.3,0.5,0.8,1.2 \mathrm{mg})$, respectively, for $1 \mathrm{~h}$ at room temperature to dissolve non-protein components. The slurry was filtered and the resultant cake was washed for 10 minby $75 \%$ aqueous alcohol $(1: 5, \mathrm{w} / \mathrm{v})$ and repeated twice. The cake was evaporated by forced air at room temperature in shallow pans under fume hood for $2 \mathrm{~h}$ to pre-remove solvent, and then dried overnight in a forced air oven at $40^{\circ} \mathrm{C}$. The dried HSPCwas ground to pass 200 mesh.

The residual activitiesof soybean lipoxygenase of HSPC, commercial SPC and DSF were measured according to the method ofabove. The crude soybean lipoxygenasewas extracted from HSPC, SPC and DSF. The reaction mixture contained $2.6 \mathrm{ml}$ boric acid buffer $(0.01 \mathrm{M}, \mathrm{pH} 9.0), 0.3 \mathrm{ml}$ linoleic acid solution and $0.1 \mathrm{ml}$ crude soybean lipoxygenase. In this experiment, the commercial SPC and DSF were used as controls to verify the inactivation effect of hexane-soluble fraction. One unit of lipoxygenaseactivity was defined as a change of 0.001 units of absorbance per minute per millilitre of enzyme extract. All measurements were an average of at least triplicate measurements.

\subsubsection{Preparation of HSPC}

HSPC used for experiments of functional properties was prepared as follow:according to Table 1, low-temperature defatted soybean flour $(80 \mathrm{~g})$ was soaked in the mixture containing $65 \%$ aqueous alcohol $(1: 10$, $\mathrm{w} / \mathrm{v}$ ) and $4.8 \mathrm{mg}$ hexane-soluble fraction for $1 \mathrm{~h}$ at room temperature to dissolve non-protein components. The slurry was filtered and the resultant cake was repeatedly washed for $10 \mathrm{~min}$ by $75 \%$ aqueous alcohol $(1: 5, \mathrm{w} / \mathrm{v})$ and repeated twice. The cake was evaporated by forced air at room temperature in shallow pans under fume hood for $2 \mathrm{~h}$ to pre-remove solvent, and then dried overnight in a forced-air oven at $40^{\circ} \mathrm{C}$. The dried HSPCwas ground to pass 200 mesh.

\subsection{Functional properties}

\subsubsection{Protein solubility}

The protein content was determined according to the method of Shi et al (Shi et al. 2011). SPC and HSPC were mixed with distilled water in the ratio of $1 / 100(\mathrm{w} / \mathrm{v})$, and then $\mathrm{pH}$ of the mixture was adjusted to 2.0, 3.0, 4.0, $4.5,5.0,6.0,7.0,8.0,9.0$ with $1 \mathrm{MNaOHorHCl}$, respectively. The suspensions were stirred at room temperature for $1 \mathrm{~h}$, and centrifuged at $8000 \mathrm{~g}$ for $15 \mathrm{~min} .6 \mu \mathrm{l}$ supernatant and $300 \mu \mathrm{lCoomassie}$ Brilliant Blue (CBB) were added into 96-well plate separately, and then read the optical density(O.D.) of the mixture at $595 \mathrm{~nm}$ and the protein content was calculated with BSA solution as the standard. All measurementswere an average of at least triplicate measurements. Protein solubility (\%) was calculated as:

$$
\text { Solubility }(\%)=\frac{\text { protein in the supernatant }}{\text { total protein }} \times 100
$$

\subsubsection{Oil absorption capacity (OAC)}

OAC was determined according tothe method of Zheng et al(Zheng et al. 2008).Protein of one gram ( $\left.\mathrm{W}_{0}\right)$ was weighed into pre-weighed $15-\mathrm{ml}$ centrifuge tubes and mixed with $10 \mathrm{ml}\left(\mathrm{V}_{1}\right)$ of soybean oil thoroughly using a vortex mixer. Samples were allowed to stand for $30 \mathrm{~min}$. The protein-oil mixture was centrifuged at $3000 \mathrm{~g}$ for $20 \mathrm{~min}$. The supernatant was poured into a $10 \mathrm{ml}$ graduated cylinder, and the volume was recorded $\left(\mathrm{V}_{2}\right)$. All measurements were an average of at least triplicate measurements. OAC ( $\mathrm{ml}$ of oil per gram of protein) was calculated as:

\subsubsection{Emulsifying properties}

$$
\mathrm{OAC}(\mathrm{ml} / \mathrm{g})=\left(\mathrm{V}_{1-} \mathrm{V}_{2}\right) / \mathrm{W}_{0}
$$

Emulsifying activity index (EAI) and emulsion stability index (ESI) of SPC and HSPC for the protein-stabilised emulsions were determined by the turbidimetric method(Wu and Wang 1998), with minor modifications. For emulsion formation, $6 \mathrm{ml}$ of $0.1 \%$ soybean protein dispersion in sodium phosphate buffer $(0.01 \mathrm{M}, \mathrm{pH} 7.0)$ and 2 $\mathrm{ml}$ of soybean oil were homogenized by T 10 basic High-Speed Homogenizer (IKA Japan Y.K.) for $1 \mathrm{~min}$ at the maximum velocity $(15000 \mathrm{rpm})$. An aliquot $(50 \mu \mathrm{l})$ of emulsion was taken from the bottom of the homogenized emulsion, immediately (0 min) and $10 \mathrm{~min}$ after homogenization, and diluted $(1: 100, \mathrm{v} / \mathrm{v})$ in $0.1 \%(\mathrm{w} / \mathrm{v})$ sodium dodecyl sulphate (SDS) solution. After vortex mixing, the absorbance of diluted emulsions was read at $500 \mathrm{~nm}$ in the spectrophotometer. All measurements were an average of at least triplicate measurements. EAI and ESI 
values were calculated by equation 4 and 5 :

$$
\operatorname{EAI}\left(\mathrm{m}^{2} / \mathrm{g}\right)=2 \mathrm{~T}\left[\frac{\left(\mathrm{A}_{0} \times \text { dilution factor }\right)}{(\mathrm{C} \times \Phi \times 10,000)}\right]
$$

where $\mathrm{T}$ was 2.303 , C was weight of protein per unit volume $(\mathrm{g} / \mathrm{ml})$ of the protein aqueous phase before emulsion formation, $\Phi$ was oil volume fraction of the emulsion ( 0.25 in this case) and the dilution factor was 100 . $\mathrm{A}_{0}$ was the absorbance of the diluted emulsions at 0 min.

$$
\operatorname{ESI}(\min )=\left(\frac{A_{0}}{\Delta \mathrm{A}}\right) \mathrm{t}
$$

For the equation $5, \mathrm{~A}_{0}$ was the absorbance of the diluted emulsion immediately after homogenisation. $\Delta \mathrm{A}$ was the change in absorbance between 0 and $10 \min \left(\mathrm{A}_{0}-\mathrm{A}_{10}\right)$ and $\mathrm{t}$ was the time interval, $10 \mathrm{~min}$ in this case.

\subsubsection{Foaming properties}

Foaming capacity (FC) and foaming stability (FS) were determined according to the method of E.Chove et al (E. Chove et al. 2007) with a slight modification. Protein $(1.5 \mathrm{~g})$ was whipped with $50 \mathrm{ml}\left(\mathrm{V}_{\mathrm{I}}\right)$ distilled water in a graduated measuring jug by a T 10 basic High-Speed Homogenizer(IKA Japan Y.K.) for 1 min at the maximum velocity $(15000 \mathrm{rpm})$. Triplicate samples of the dispersions were blended and all measurements were an average of at least triplicate measurements. The volume of foam $\left(\mathrm{V}_{\mathrm{F}}\right)$ was immediately recorded. FC was calculated using the following equation:

$$
\mathrm{FC}=\mathrm{V}_{\mathrm{F}} / \mathrm{V}_{1}
$$

The remained volume of foam $\left(\mathrm{V}_{\mathrm{F}}\right)$ was recorded after $2 \mathrm{~h}$ at $25^{\circ} \mathrm{C}$, FS was calculated using the following equation:

$$
\mathrm{FS}=\mathrm{V}_{\hat{\mathrm{F}}} / \mathrm{V}_{1}
$$

\subsection{Statistical analysis}

Experiments were repeated three times. Experimental results were given as means \pm S.D. of three replicate measurements. Analysis of significant difference was performed by Excel of Microsoft.

\section{Result and Discussion}

\subsection{The inhibition of cucumber extracts on lipoxygenase}

The inhibition of soybean lipoxygenase activity by cucumber extracts were presented in Figure.1. The hexane-soluble fraction showed the highest inhibition ratio.The inhibition of hexane-soluble fraction exhibited concentration dependence and $\mathrm{IC}_{50}$ value of $1.08 \pm 0.11 \mathrm{mg} / \mathrm{ml}$ was calculated. The inhibition of EtOAc-soluble fraction, $\mathrm{BuOH}$-soluble fraction and $\mathrm{MeOH}$-soluble fractions were exhibited very less inhibition on soybean lipoxygenase activity.Therefore, the hexane-soluble fraction was used as theinhibition the following experiments.

\subsection{Residual activity of soybean lipoxygenase of HSPC}

The residual activity of HSPC lipoxygenasevalues were showed in Table 1.The minimum residual activity of lipoxygenaseof HSPC $(3.77 \pm 0.69 \mathrm{U})$ was observed at the ratio of $0.3 \mathrm{mg}$ cucumber hexane-soluble fraction to 5 g DSF.It was not exhibited concentration dependence. It may be due to the HSPC was prepared by the mixture of alcohol and hexane-soluble fraction, therefore, alcohol induced protein aggregation and theninfluenced the inhibition of cucumber hexane-soluble fraction on soy lipoxygenase. Meanwhile, lipoxygenase activity of commercial SPC and DSF were determined and they were1.55 $\pm 0.19 \mathrm{U}$ and $1965.11 \pm 21.74 \mathrm{U}$, respectively.The residual lipoxygenase activity of HSPC was obviously reduced by alcohol and cucumber hexane-soluble fraction compared with the residual lipoxygenase activity of DSF. Although the minimum residual activity of HSPC ( $3.77 \pm 0.69 \mathrm{U})$ was higher than SPC $(1.55 \pm 0.19 \mathrm{U})$, the characteristic flavors of soybean could not be smelled out at the residual lipoxygenase activity of HSPC with $3.77 \pm 0.19 \mathrm{U}$. Therefore,HSPC used in the following experimentswas prepared according to the ratio of $0.3 \mathrm{mg}$ cucumber hexane-soluble fraction to $5 \mathrm{~g}$ DSF. 


\subsection{Functionality of HSPC}

\subsubsection{Protein solubility}

The solubility of HSPC was measured at various $\mathrm{pH}$. Figure 2 showed that at the $\mathrm{pH}<3$ or $\mathrm{pH}>6, \mathrm{HSPC}$ showed superior solubility compared with commercial SPC and there was a significant difference. Protein solubility were $16.54 \%, 30.11 \%, 34.13 \%$ and $47.54 \%$, comparison with commercial SPC $4.95 \%, 8.93 \%, 13.69 \%$ and $20.24 \%$ at $\mathrm{pH} 2,7,8$ and 9 , respectively. At the $\mathrm{pH}$ around isoelectric point $\mathrm{pH}(3.0,4.0,4.5,5.0,6.0)$, HSPC and commercial SPC showed similar low solubility.The protein solubility is influenced by the hydrophilicity/hydrophobicity balance, which depends on the amino acid composition, particularly at the protein surface. Higher solubility is related with the presence of a low number of hydrophobic residues, the elevated charge and the electrostatic repulsion and ionic hydration occurring at $\mathrm{pH}$ above and below the isoelectric $\mathrm{pH}$. Moreover, the denaturationcan alter the hydrophobicity/hydrophilicity ratio of the surface to increase hydrophobic surface was reported in Kilara and Moure(Kilara et al. 1986; Moure et al. 2006). Therefore the increase of protein solubility may be by the reason that the raw material of HSPC (low-temperature defatted soybean flour)weakened the influence of denaturation on protein solubility.

\subsubsection{Oil absorption capacity (OAC)}

Oil absorption values of HSPC and SPC were showed in Table 2. The oil absorption of HSPC exhibited significant difference at $1.18 \mathrm{ml} / \mathrm{g}$ compared with commercial SPC at $0.88 \mathrm{ml} / \mathrm{g}$. Fat absorption capacity is the binding of fat by nonpolar side chains of proteins (Deshpande et al. 1982). Heat treatment made the protein denaturation tends to unfold the protein molecule to increase its effective hydrophobicity. Therefore it is considered that the SPCshould show the better oil absorption capacity than HSPC. On the contrary,the HPSC exhibited superior oil absorption capacity compared with commercial SPC. It may be for the reason that cucumber hexane-soluble fraction could influence the structure of protein molecule to expose more hydrophobic group or could combine with protein molecules toincrease the amount of hydrophobic group of protein molecule surface.

\subsubsection{Foaming properties}

Foaming properties is reflected by foaming capacity and foaming stability. The foaming characterizations of HSPC and commercial SPC wereshowed in Table 2. It was observed that HSPC was similar to FC at $86.67 \%$ and no significantdifference from the commercial SPC at $88 \%$.HSPC exhibited excellent FS at $73.67 \%$ and was different from commercial SPC at $47 \%$ significantly, after incubated 2 h.Foam capacity is determined by the ability of the protein to reduce the surface tension, the molecular flexibility and physico-chemical properties (hydrophobicity, net charge and charge distribution, hydrodynamic properties) (Moure et al. 2006). Heat treatment and alcohol washing can improve protein emulsifying and foaming properties (Morr 1990; Hua et al. 2005). Table 2 showed that hexane-soluble fraction could improve protein foaming capacity of HSPC.It may be because of increasing the amount of hydrophobic group of protein molecule surface by cucumber hexane-soluble fraction.

\subsubsection{Emulsifying properties}

Emulsifying activity index and emulsion stability index values of HSPC and SPC were showed in Table 2. It was observed that HSPC exhibited superior EAI at $102.68 \mathrm{~m}^{2} / \mathrm{g}$ compared with the commercial SPC at $96.72 \mathrm{~m}^{2} / \mathrm{g}$. The HSPC also showed superior ESI at 34.44 per min compared with commercial SPC at 16.47 per min. The emulsifying properties of protein largely depend on a proper balance between hydrophilic and lipophile groups. Heat treatment made the protein denaturation tends to unfold the protein molecule to increase its effective hydrophobicity. On the contrary, HSPC which was not underwent heat treatment exhibited higher EAI and ESI than SPC.Thus it suggested that the hexane-soluble fraction could improve the emulsifying properties. It may be by the reason that cucumber hexane-soluble fraction could influence the structure of protein molecule to expose more hydrophobic group or could combine with protein molecules and thus increase the amount of hydrophobic groups of protein molecule surface.

\section{Conclusions}

The cucumber hexane-soluble fraction could inhibit the activity of lipoxygenase effectively and exhibited concentration dependence manner.At the ratio of $0.3 \mathrm{mg}$ hexane-soluble fraction to $5 \mathrm{~g}$ DSF, the minimum residual lipoxygenase activity was observed.Comparing with commercial SPC, HSPC showed superior oil absorbent capacity, foaming property, emulsifying property and superior solubility at the $\mathrm{pH}<3$ or $\mathrm{pH}>6$, similar low solubility at the $\mathrm{pH}$ around isoelectric point $\mathrm{pH}$.In brief, the addition of cucumber hexane-soluble fraction in the production process of SPC using low-temperature defatted soybean flour could improve 
functional properties of SPC.The cucumber extract could be a substitute for normal thermal treatment to inhibit lipoxygenase activity.In the future, it will be focused on component analysis aiming at cucumber hexane-soluble fraction and the relationship between protein molecular structure and hexane-soluble fraction.

\section{References}

Anderson, R. L. (1992). Effect of steaming on soybean proteins and trypsin inhibitors. Journal of the American Oil Chemists, 69, 1170-1176. http://dx.doi.org/10.1007/BF02637675

Andreou, A.,I. Feussner. (2009). Lipoxygenases - Structure and reaction mechanism.Phytochemistry, 70(13-14), 1504-1510. http://dx.doi.org/10.1016/j.phytochem.2009.05.008

Deshpande, S. S., S. K. Sathe \& D. K. Salunkhe. (1982). Functional Properties of Winged Bean [Psophocarpustetragonolobus (L.) DC] Proteins. Journal of Food Science, 47(2), 503-509. http://dx.doi.org/10.1111/j.1365-2621.1982.tb10112.x

E. Chove, B., A. S. Grandison \& M. J. Lewis. (2007). Some functional properties of fractionated soy protein isolates obtained by microfiltration. Food Hydrocolloids, 21(8), 1379-1388.

Emmert, J. L. \& D. H. Baker. (1995). Protein quality assessment of soy products. Nutrition Research, 15(11), 1647-1656. http://dx.doi.org/10.1016/0271-5317(95)02035-5

Feußner, I. \& H. Kindl. (1992). A lipoxygenase is the main lipid body protein in cucumber and soybean cotyledons during the stage of triglyceride mobilization.. FEBS Letters, 298(2-3), 223-225. http://dx.doi.org/10.1016/0014-5793(92)80062-1

Hanqing, W. (1996). Affecting the activity of soybean lipoxygenase-1. Journal of Molecular Graphics, 14(6), 331-337. http://dx.doi.org/10.1016/s0263-7855(97)00006-4

Hua, Y., Y. Huang, A. Qiu \& X. Liu. (2005). Properties of soy protein isolate prepared from aqueous alcohol washed soy flakes. Food Research International, 38(3), 273-279. http://dx.doi.org/10.1016/j.foodres.2004.05.010

Indrawati, I., L. R. Ludikhuyze, A. M. V. Loey \& M. E. Hendrickx. (2000). Lipoxygenase Inactivation in Green Beans (Phaseolus vulgaris L.) Due to High Pressure Treatment at Subzero and Elevated Temperatures. J. Agric. Food Chem, 48(5), 1850-1859. http://dx.doi.org/10.1021/jf990937n

Ivanov, I., D. Heydeck, K. Hofheinz, J. Roffeis, V. B. O’Donnell, H. Kuhn \& M. Walther. (2010). Molecular enzymology of lipoxygenases. Archives of Biochemistry and Biophysics, 503(2), 161-174. http://dx.doi.org/10.1016/j.abb.2010.08.016

Kermasha, S., N. Dioum, B. Bisakowski \& M. Vega. (2002). Biocatalysis by immobilized lipoxygenase in a ternary micellar system. Journal of Molecular Catalysis B: Enzymatic, 19-20(0), 305-317. http://dx.doi.org/10.1016/s1381-1177(02)00181-9

Kilara, A., T. Y. Sharkasi \& C. V. Morr. (1986). Effects of temperature on food proteins and its implications on functional properties. Food Science and Nutrition, 23(4), 323-395.

Kong, X., X. Li, H. Wang, Y. Hua \& Y. Huang. (2008). Effect of lipoxygenase activity in defatted soybean flour on the gelling properties of soybean protein isolate. Food Chemistry, 106(3), 1093-1099. http://dx.doi.org/10.1016/j.foodchem.2007.07.050

Morr, C. (1990). Current status of soy protein functionality in food systems. Journal of the American Oil Chemists' Society, 67(5), 265-271.

Moure, A., J. Sineiro, H. Domínguez \& J. C. Parajó. (2006). Functionality of oilseed protein products: A review. Food Research International, 39(9), 945-963. http://dx.doi.org/10.1016/j.foodres.2006.07.002

Rackis, J., D. Sessa \& D. Honig. (1979). Flavor problems of vegetable food proteins. Journal of the American Oil Chemists' Society, 56(3), 262-271.

Shi, M., Y. Yang, Y. Li, Y. Wang \& Z. Zhang. (2011). Optimum Condition of Ecologic Feed Fermentation by PleurotusOstreatus Using Soybean Curd Residue as Raw Materials. International Journal of Biology, 3(4), 2-12. http://dx.doi.org/10.5539/ijb.v3n4p2

Sorgentini, D. A., J. R. Wagner \& M. C. Anon. (1995). Effects of Thermal Treatment of Soy Protein Isolate on the Characteristics and Structure-Function Relationship of Soluble and Insoluble Fractions. Journal of Agricultural and Food Chemistry, 43(9), 2471-2479. http://dx.doi.org/10.1021/jf00057a029

Tiziani, S. \& Y. Vodovotz. (2005). Rheological effects of soy protein addition to tomato juice. Food 
Hydrocolloids, 19(1), 45-52. http://dx.doi.org/10.1016/j.foodhyd.2004.04.012

Wu, Y. \& Z.-X. Wang. (1998). Comparison of conformational changes and inactivation of soybean lipoxygenase-1 during urea denaturation. Biochimica et BiophysicaActa (BBA) - Protein Structure and Molecular Enzymology, 1388(2), 325-336.

Yen, G.-C., Y.-C. Chang \& S.-W. Su. (2003). Antioxidant activity and active compounds of rice koji fermented with Aspergilluscandidus. Food Chemistry, 83(1), 49-54. http://dx.doi.org/10.1016/s0308-8146(03)00035-9

Yukawa, N., Y. Takahashi, T. Fujimura, et al. (1992). Alcohol Formation from Aldehydes by Endogeneous Alcohol Dehydrogenase in Soybean Extracts. Journal of home economics of Japan, 43(3), 193-198.

Zheng, H.-G., X.-Q. Yang, C.-H. Tang, L. Li \& I. Ahmad. (2008). Preparation of soluble soybean protein aggregates (SSPA) from insoluble soybean protein concentrates (SPC) and its functional properties. Food Research International, 41(2), 154-164. http://dx.doi.org/10.1016/j.foodres.2007.10.013

Table 1. Theresidual activity of soybean lipoxygenase of HSPC

\begin{tabular}{|c|c|c|c|c|c|}
\hline \multirow{2}{*}{ Sample } & \multicolumn{5}{|c|}{ amount (mg) } \\
\cline { 2 - 6 } & 0.2 & 0.3 & 0.5 & 0.8 & 1.2 \\
\hline HSPC & $10.44 \pm 0.19$ & $3.77 \pm 0.69$ & $6.33 \pm 0.33$ & $18.00 \pm 0.33$ & $20.33 \pm 0.88$ \\
\hline
\end{tabular}

One unit of lipoxygenase activity was defined as a change of 0.001 units of absorbance per minute per millilitre of enzyme extract.

SPC and DSF were controls.

Standard error of the mean of three assays.

Table 2. Compare of functional properties of HSPC and commercial SPC

\begin{tabular}{|l|l|l|}
\hline Functional properties & HSPC & SPC \\
\hline Solubility at pH $7.0(\%)$ & $30.11 \pm 2.67^{\mathrm{a}}$ & $8.93 \pm 0.23^{\mathrm{a}}$ \\
\hline Oil absorption capacity $(\mathrm{ml} / \mathrm{g})$ & $1.18 \pm 0.05^{\mathrm{a}}$ & $0.88 \pm 0.03^{\mathrm{a}}$ \\
\hline Emulsifying activity index $\left(\mathrm{m}^{2} / \mathrm{g}\right)$ & $102.68 \pm 2.2^{\mathrm{a}}$ & $96.72 \pm 0.59^{\mathrm{a}}$ \\
\hline Emulsifying stability index (min) & $32.44 \pm 1.79^{\mathrm{a}}$ & $16.47 \pm 0.11^{\mathrm{a}}$ \\
\hline Foaming capacity (\%) & $86.67 \pm 3.06^{\mathrm{c}}$ & $88.00 \pm 2.00^{\mathrm{b}}$ \\
\hline Foaming stability (\%) & $73.67 \pm 3.79^{\mathrm{a}}$ & $47.33 \pm 2.31^{\mathrm{a}}$ \\
\hline
\end{tabular}

Date was expressed as means (SD) of triplicate experiments.

a: $\mathrm{p}<0.01, \mathrm{~b}: \mathrm{p}<0.05$, c: no significant difference. 

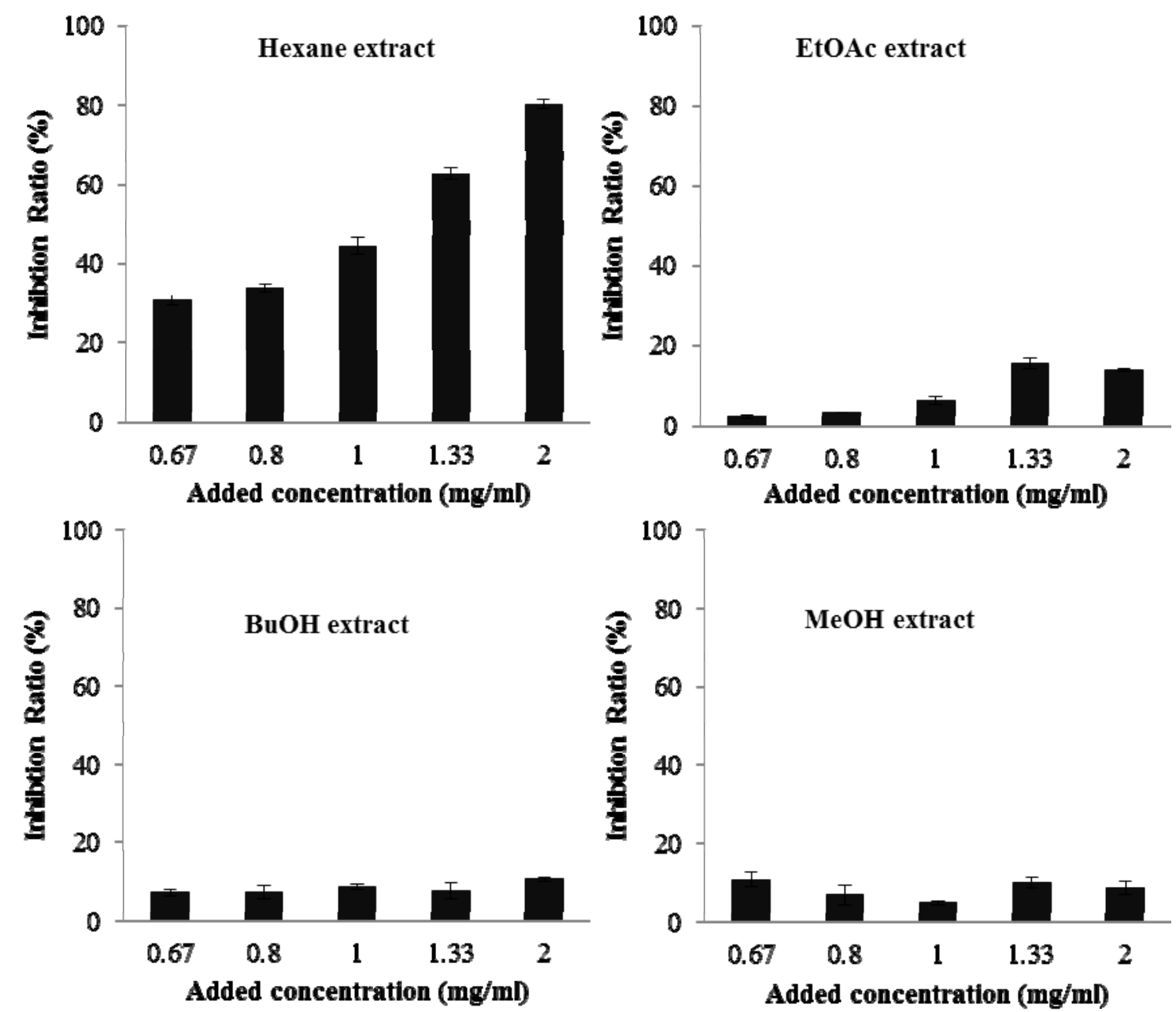

Figure 1. Inhibition of soybean lipoxygenase activity by hexane, EtOAc, $\mathrm{BuOH}, \mathrm{MeOH}$ soluble fraction at various concentration $(0.67,0.8,1.0,1.33,2.0 \mathrm{mg} / \mathrm{ml}) .(\mathrm{mean} \pm \mathrm{SD}, \mathrm{n}=3)$

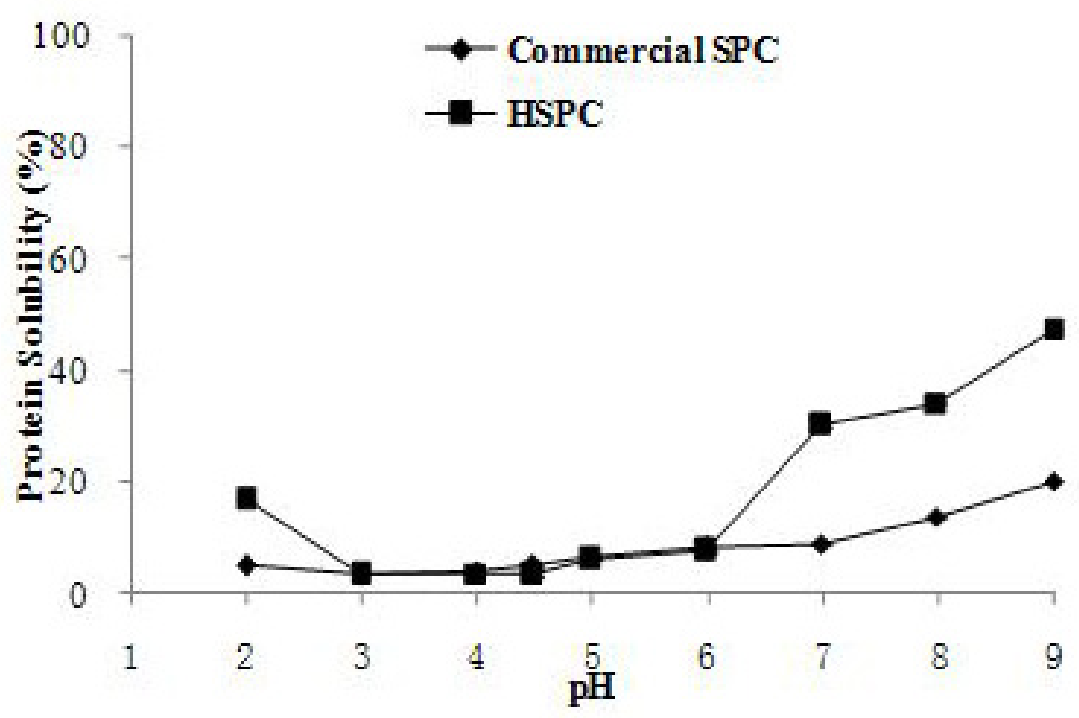

Figure 2. Solubilityof HSPC and commercial SPC atdifferentpH.Standard error of the mean of three assays 